Acta vet. scand. $1960,1,161-187$.

From The Royal Veterinary and Agricultural College, Department of Pathological Anatomy, Copenhagen, and The Veterinary Institute, Oslo.

\title{
MELANOSIS RENUM BOVIS
}

\section{By}

Rolf Svenkerud.

The term "melanosis renum bovis" in the present study applies to an anomaly in cattle known as black kidneys. The anomaly is characterized by a dark brown or almost black discoloration of the kidneys. It si due to a deposition of pigment in the epithelial cells of certain portions of the renal tubules. These changes have been subjected to closer study, and attempts have been made to determine the nature of the pigment. Minor pigment deposits have also been demonstrated in other organs than the kidneys. The occurrence of the anomaly among various breeds in different countries has been dealt with.

The icteric discoloration of the kidneys in calves often referred to as "melanosis renum" has nothing to do with melanosis and will not be considered in the present study.

\section{PREVIOUS INVESTIGATIONS}

In the comparatively sparse literature dealing with "black kidneys of cattle" opinions differ as to the nature of the anomaly.

The first comprehensive study of the anomaly was carried out by Roth (1903) who examined 5 cases, 2 of them his own and $3 \mathrm{mu}-$ seum specimens. Roth found that the discoloration was due to a deposition of pigment in "den gewundenen Canälchen, Schaltstück und den aufsteigenden Schenkelen der geraden Canälchen" or in what he calls "den secernirenden Epithelien." On the basis of chemical analysis he concluded that the pigment was a melanin. In cases with excessive pigmentation he found damage of the tubular epithelium, a condition which he refers to as "a moderate excretory nephritis". In sections of liver and spleen he found no pigment deposits, nor could any pathologic changes be demonstrated. Roth considered the anomaly an acquired lesion and suggested that "an anomaly of the blood might 
give rise to deposition of a pigment which, together with other proteins in the cells might provide material for the formation of melanin".

Hemmert-Halswick (1929) investigated 5 cases from Berliner Schlachthof. He found pigment deposits in the secretory portions of the tubules and to a less extent also in the glomeruli and collecting tubules. In 4 of the cases the deposits were hemosiderin and in 1 case a pigment which gave the reactions of lipofuscins. He believed that the condition is due to previous hemolysis.

Bos (1936) described the case of an 8 years old cow. He found a pigment which he termed "wear-and-tear pigment" ("Abnutzungspigment") in the cells of the proximal convoluted tubules and their straight terminal portions, and to a less extent in the loops of Henle and the collecting tubules.

Joest (1924) states that the pigment is deposited in the convoluted tubules and ascending limbs of the loops of Henle. He says that some authors consider the pigment a melanin, while others consider the condition that of a hemochromatosis. Himself he supports the latter view.

Kitt (1927) believes that the condition might be that of a pigmentation resulting from choluria in calves. The color of the pigment he describes as yellowish green to dark brown and states that the site of pigmentation is the convoluted tubules and the loops of Henle.

Nierberle and Cohrs (1954) in the last edition of their text-book state that the pigment gives the reactions of lipofuscins and is found only in the secretory portions of the nephron, particularly in "pars medullaris von Hauptstück III."

\section{MATERIAL AND METHODS}

The material studied was collected at the slaughter-house of Copenhagen. Specimens of different organs were removed immediately after death and transferred to various fixation fluids. Frozen sections were also prepared for special examinations. Renal tissue was removed from 50 animals with "black kidneys" for further examination. Specimens of liver, spleen, lymph nodes and bone marrow, and urine were also collected in some instances. The urine samples were taken directly from the bladder after slaughtering. Similar specimens of organs and urine serving as controls were removed from animals not presenting macroscopic kidney lesions.

The fixation fluids used were formalin (partly buffered, neutral, and partly non-buffered, acid), Müller's fluid, Zenker's solution, Susa's fluid, and alcohol.

For staining of survey sections use was made of Meyer's 
hemalum, hemalum-eosin, azan, van Gieson, and resorcin-fuchsin after Weigert combined with van Gieson.

For determination o fvarious cell types sections were stained with hemalum-eosin (eosin 1:10.000 for approx. 20 hours), methylgreen-pyronine after Unna, and metachromatic staining with toluidine blue. For histochemical study use was made of various methods which are described later in the text. Solubility of the pigment was studied partly by adding different solvents under the cover glass of mounted sections and partly by emerging sections affixed to slides in the respective solvents.

\section{RENAL CHANGES}

The pigmentation. The main feature in melanosis renum bovis is that of a brownish to dark brown discoloration of the kidneys in an apparently healthy animal. The degree of pigmentation varies. In some instances it may be so intense that the kidneys take a bluish black, glistening appearance. The discoloration involves the entire organ, and both kidneys are equally affected to the same degree. At a first gance the appearance is that of a uniform discoloration but closer inspection reveals a delicate network of dark brown to black crisscrossing streaks (fig. 1), or a dark ground diversified with small greyish dots (fig. 2). The finer structure depends on the distribution of the pigment in the tubules and will be considered later in the text.

The renal capsule and surrounding fat are normal. The cut surface shows pigmentation of the cortex and a narrow brim of the boundary zone of the medulla. The cortex is traversed by alternate light grey and darker pigmented lines and rays arranged in a radiating manner. The narrow boundary zone of the medulla is more evenly and usually less severely pigmented than the cortex. The medulla is otherwise normal, and so are also the renal pelvis and ureter.

Microscopic examination shows deposits of a glistening yellow or yellowish brown pigment in the cells of certain portions of the tubules. In thicker layers the pigment attains a darker color. It forms granules of varying sizes, some of them very small, with a diameter less than $1 \mu$, others forming flakes larger than the nuclei of the cells. The flakes often have an irregular shape; some of them seem to be formed by a fusing of smaller elements, while others have a more homogenous appearance. A feature 


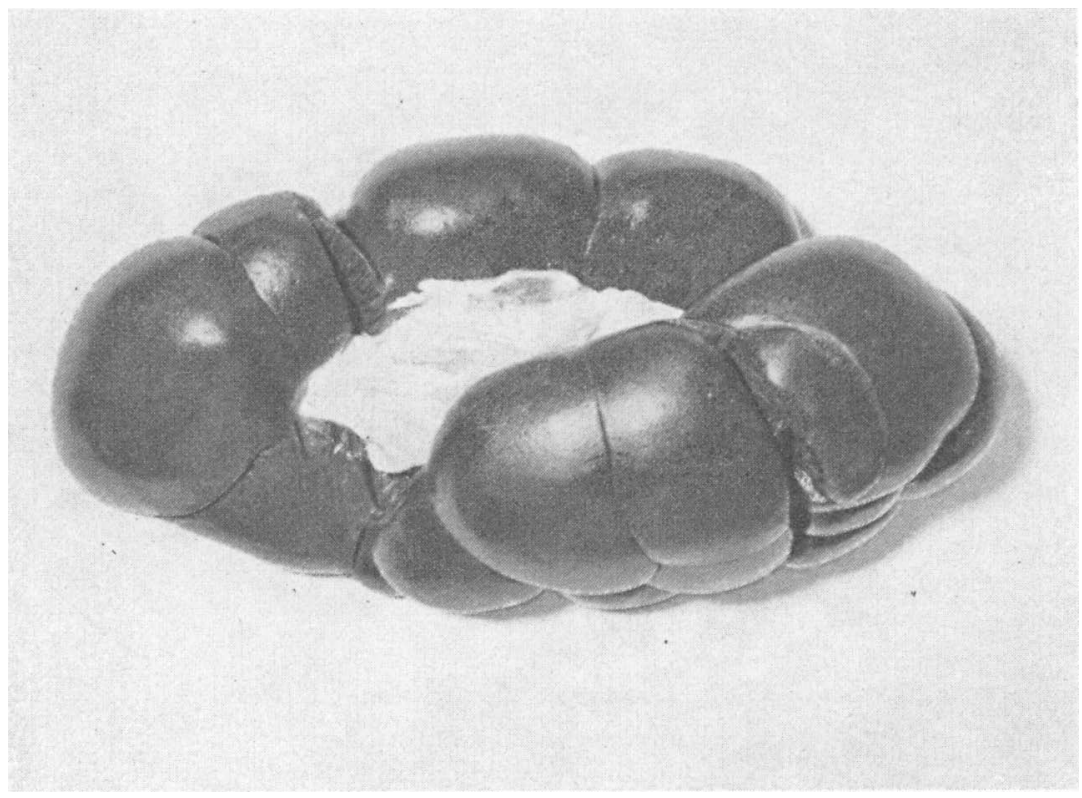

Fig. 1. Kidney showing marked pigmentation. The hilus fat is normal. The surface of the kidney shows a netlike pattern.

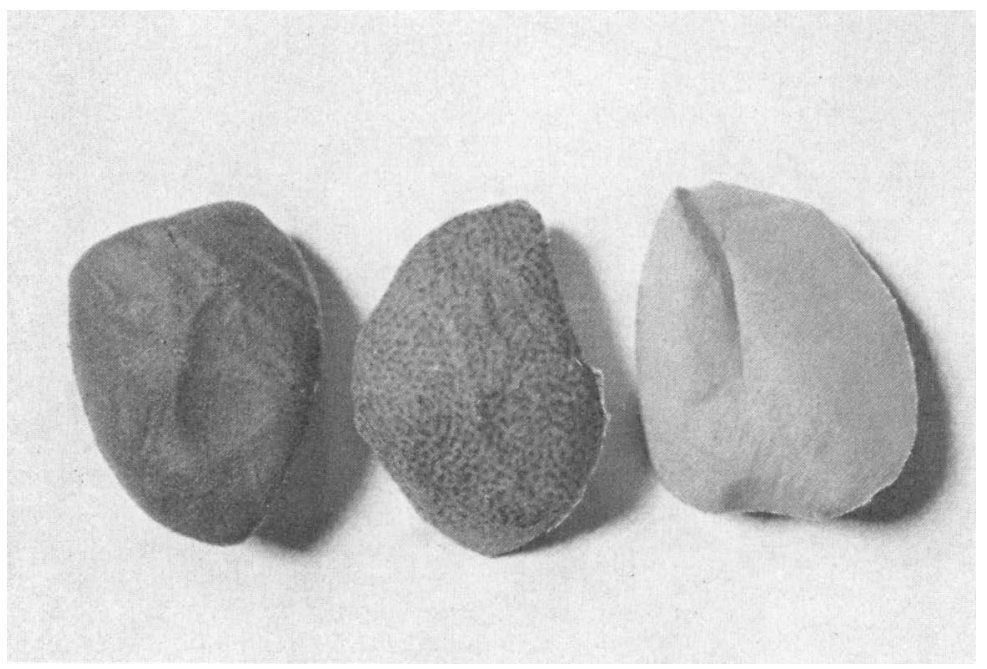

F i g. 2. Renculi removed from 3 different kidneys, 2 of them pigmented and 1 normal, all of them fixed in 10 per cent formalin. Color pattern and difference in color are well seen. 
often emphasized is the columnar arrangement of granules basally in the cells so as to give the impression of radiate streaking.

In order to determine the exact site of pigmentation, sections were prepared and stained for alkaline phosphatase (CalciumCobalt method of Gomori, after Glick, with short fixation of small tissue specimens in alcohol and rapid embedding in paraffin without using vacuum). Macerated preparations were also made. By the first-mentioned method the proximal convoluted tubule and its straight terminal portion are easily distinguished as there in these portions is a precipitation of cobalt sulfide in the brush borders.

It was impossible to obtain usable macerated preparations by the use of hydrochloric acid on fresh material. Better results were obtained by the use of material fixed for a minimum of eight days in a 10 per cent formalin solution. For maceration use was made of concentrated hydrochloric acid (specific gravity $1.19)$.

The proximal convoluted tubule and its straight terminal portion were found to be the site of pigmentation. Pigmentation may be more marked in the proximal convoluted tubules and less in their terminal portions, or vice versa. In the first event the surface pattern is that of light greyish dots on a dark ground; in the latter event it is that of dark dots on a lighter ground. The gross appearance may vary between these extremes according to the distribution of the pigment. In some instances the pigment is found practically only in the straight terminal portions of the proximal convoluted tubules and the adjacent part of proximal convoluted tubules. This gives a delicate network of pigmented lines on a greyish ground. The pattern is usually uniform with similar involvement of both kidneys in the same animal. However, the pattern may also be that of alternate pigmented dots and lines on a lighter ground due to a different location of the pigment in the individual nephrons.

The pigment deposits in the nephrons causes a radiate streaking of the cortex. If pigmentation is chiefly localized to the proximal convoluted tubules, the cortex is traversed by dark lines tapering towards the medulla. If the straight terminal portions of the convoluted tubules are the chief site of pigmentation the lines will be tapering towards the surface of the organ. This difference, however, is seldom very marked although there 
is usually a striking uniformity with regard to the distribution of the pigment in the individual nephrons.

The neck often contains pigment granules, and deposits may occasionally be found also in the parietal layer of the capsule of Bowman. The remaining parts of the nephron are seldom involved, but isolated pigment granules may occasionally be seen in the cytoplasm of the cells of the distal convoluted tubules and collecting tubules, particularly in severe cases. In a few instances I have also seen a few isolated granules in the ascending limb of the loop of Henle.

The site of pigmentation is the renal parenchyma, while vessels and connective tissue do not seem to be involved. However, on a few occasions I have observed sparse deposits also in these tissues in the form of small granules in comparatively large mesenchymal cells (melanophores) and in the endothelium of lymph vessels. In a few instances $I$ have observed pigment deposits in the lumen of the collecting tubules.

Figure 3 is a drawing from a macerated and microdissected preparation showing marked pigmentation in the distal portions of the proximal convoluted tubule.

Figure 4 is a drawing of some areas of a hemalum-stained section. Pigment deposits are seen in the parietal layer of the capsule of Bowman, in the neck and in a loop of the proximal convoluted tubule and its straight terminal portion. The transition from the straight terminal portion of the proximal convoluted tubule to the loop of Henle and the cessation of pigmentation at this junction can be seen very clearly.

\section{CHANGES OTHER THAN PIGMENTATION}

In some cases of black kidneys there may be no demonstrable abnormality of the renal tissue apart from the pigmentation. Comparatively many epithelial cells which are cast off into the tubular spaces may be seen in some areas, particularly in areas being the site of heavy pigmentation. The general impression, however, is that there is remarkably little damage of the epithelium even in the presence of severe pigmentation of the cells. In sections stained for alkaline phosphatase there is usually evidence of marked phosphatase activity even in areas severely involved. This seems to indicate that the cellular function is well preserved. There may be no pathologic changes of the vessels 


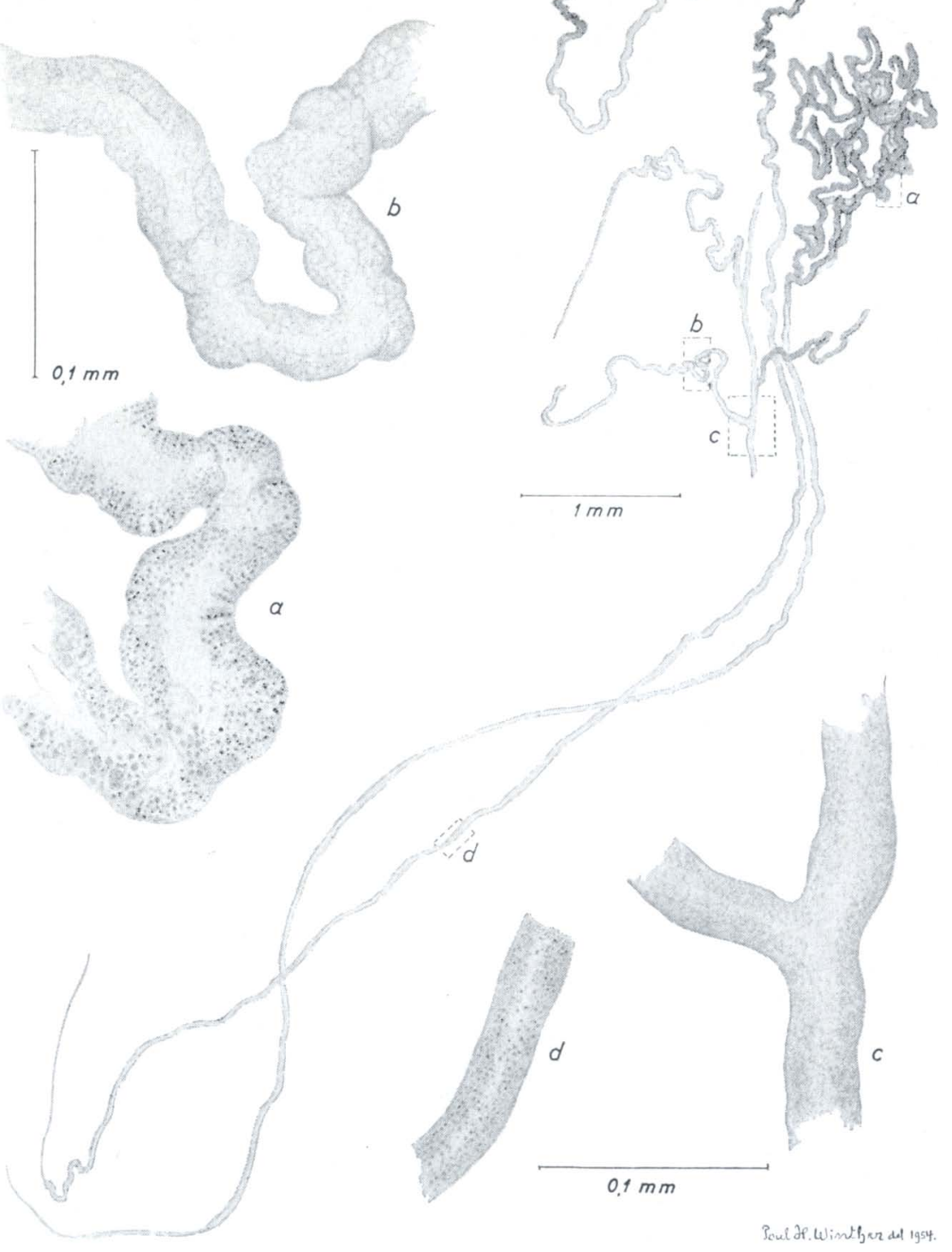

F i g. 3. Drawing of isolated nephrons with high power views of individual portions. Pigmentation is most marked in the distal portion of the proximal convoluted tubule.

a) High power view of proximal convoluted tubule. Pigment granules of varying sizes showing rodlike arrangement and radiate striping. b) High power of the distal convoluted tubule. Some indistinct granules are seen but these are not pigment. Similar granules are seen in the connecting part of the distal convoluted tubule (c).

d) High power view of straight terminal portion of the proximal convoluted tubule. Here the pigment granules are small and more uniform in size than in the proximal convoluted tubule. 

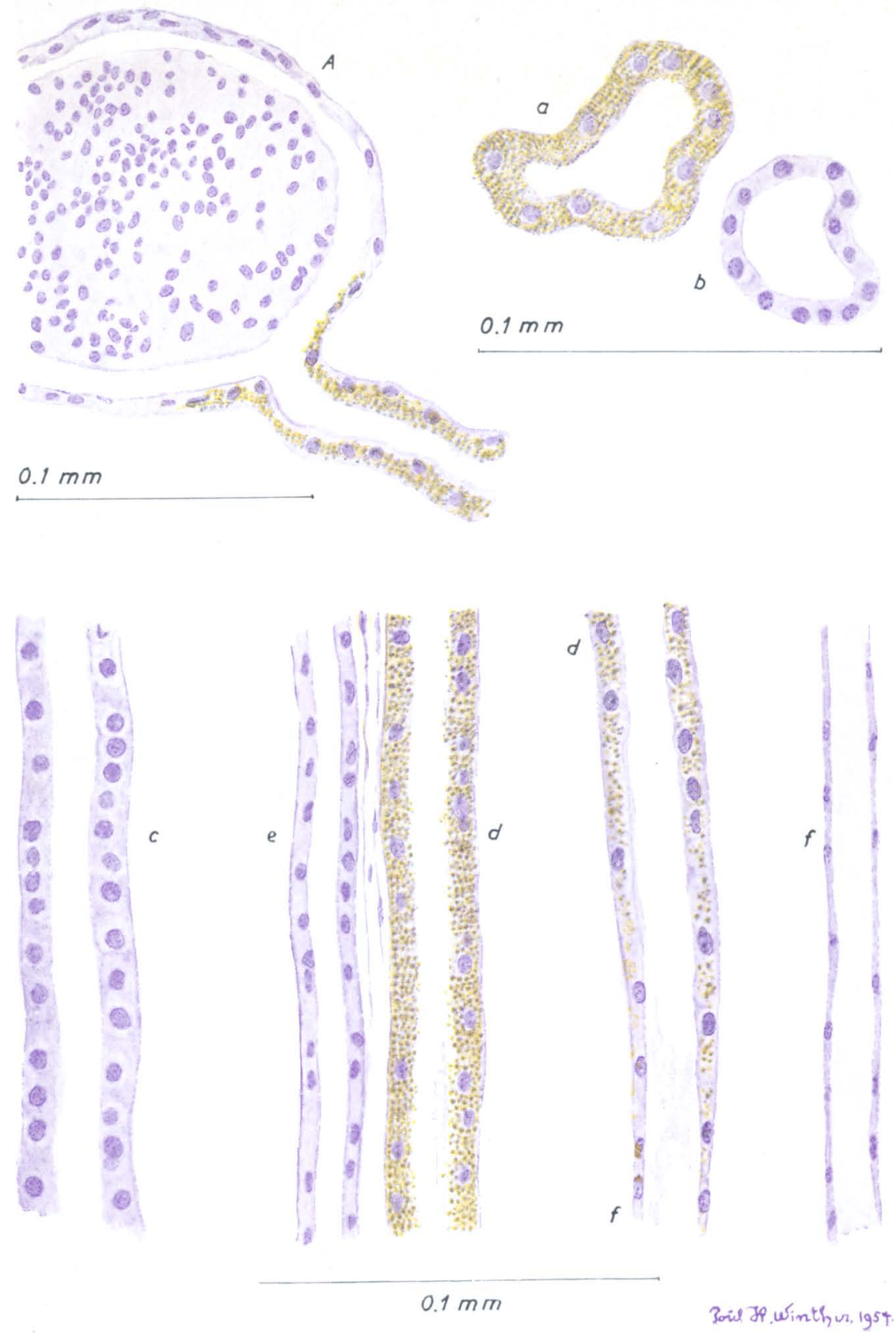

F i g. 4. A. Pigment deposits can be seen in the parietal layer of the capsule of Bowman.

a) Cross section of proximal convoluted tubule with pigment.

b) Cross section of distal convoluted tubule without pigment.

c) Collecting tubule without pigment.

d) Straight terminal portion of the proximal convoluted tubule with pigment.

e) Ascending loop of Henle without pigment.

f) Bend of the loop of Henle without pigment.

d-f) Transition from d) to $f$ ).

Drawn from a hemalum-stained section. 
and connective tissue. However, the interstices may frequently be the site of inflammatory changes which may be intertubular, pericapsular or perivascular. They may take the appearance of small cellular infiltrates often entirely composed of plasma cells as frequently seen in the bovine kidney in the absence of pigmentation or other pathologic conditions. Extensive involvement may sometimes be observed, and the cellular infiltrates may be rather large and may contain large numbers of lymphocytes. There may also be histiocytes and proliferation of fibroblasts with formation of collagenous tissue. Polymorphonuclear cells, usually eosinophils may occasionally be seen. The pericapsular lesions usually take the appearance of small cellular infiltrations with associated fibrous tissue proliferation and hyalinization. The perivascular changes appear as small, nodular infiltrations of cells in the adventitia. The intertubular lesions are always focal but may be widely distributed in the organ.

More marked changes are usually associated with damage of individual tubules and glomeruli. The latter structures attain an irregular shape and may be small and sclerotic; there may be proliferation of the capsular epithelium. The tubules may be shrunken and atrofic, and the cells are then often loaded with pigment. Pigmented cells may also lie free in the lumen of the tubules and form cellular casts, or the narrow lumen may be filled with granular pigment. In other areas the tubules are dilated, with a low epithelium. Rarely there may be migrating cells and cast formation in the tubuli. Sections stained with toluidine blue show numerous mast cells perivascularly and in the interstitial tissue. This is also the case in black kidneys presenting no or merely slight inflammatory changes.

The question naturally arises as to the possibility of a definite relation between the pigmentation and the inflammatory changes. In areas presenting marked interstitial changes there is usually severe pigmentation of the tubular epithelium. In other areas, however, severe pigmentation may be seen in the absence of inflammatory changes, and an increase in the amount of interstitial connective tissue may be seen in areas showing only slight pigmentation of the tubular epithelium. These circumstances seem to indicate the involvment of different etiological factores in the production of the two types of lesion (inflammatory changes and pigmentation).

In an effort to elucidate this problem specimens for sectioning 
were removed from 25 slaughter beasts not presenting macroscopic renal changes. This beasts were of nearly the same age as those animals from which the pigmented kidney material was taken. Interstitial lesions in the form of small scattered cellular infiltrates were demonstrated in the kidneys of a large proportion of these animals. The smaller lesions were mainly composed of plasma cells, while the larger ones usually contained lymphocytes as well. Productive inflammatory changes in the form of localized fibrous tissue proliferation in the interstices were more rarely encountered.

Of the 50 black kidneys studied, 38 (76 per cent) showed inflammatory changes in the interstices. Of these, 12 (24 per cent) showed cellular infiltrates alone, while 26 (52 per cent) showed more chronic inflammatory changes with localized fibrous tissue proliferation. The corresponding figures for the control group were 52, 40 and 12 per cent, respectively.

A statistical analysis (table 1) showed no significant difference with regard to the occurrence of inflammatory lesions

Table 1.

\begin{tabular}{c|c|c|c|c|c|c|c|c|c|c}
\hline Material & $\begin{array}{c}\text { Number } \\
\text { studied }\end{array}$ & No./Infl. & $\mathrm{P}$ & $\xi_{\mathrm{D}}$ & No./Chr.prol. & $\mathrm{P}$ & $\xi_{\mathrm{D}}$ & No./Infiltr. & $\mathrm{P}$ & $\xi_{\mathrm{D}}$ \\
\hline $\begin{array}{c}\text { Black } \\
\text { kidney }\end{array}$ & 50 & 38 & 0.76 & & 26 & 0.52 & & 12 & 0.24 & \\
\hline Control & 25 & 13 & 0.52 & & 3 & 0.12 & & 10 & 0.40 & \\
\hline
\end{tabular}

No./Infl. = Number of kidneys with inflammatory changes in the interstices.

No./Chr.prol. = Number of kidneys with chronic proliferative changes in the interstices.

No./Infiltr. = Number of kidneys with focal cellular infiltrates in the interstices without definite fibrous tissue proliferation.

$P=$ Relative incidence.

$\xi_{\mathrm{D}}=$ Mean error of the difference.

in the two groups when the more acute and the chronic changes were considered collectively. The incidence of chronic proliferative changes, on the other hand, was definitely higher in the series of black kidneys than in the control group, while no definite difference could be demonstrated with regard to the incidence of inflammatory changes of a more acute nature. 
Changes in the lymph nodes.

A greyish or greyish black discoloration of the renal lymph nodes can occisionally be seen in cases of black kidneys, particularly in the presence of marked pigmentation.

Histological examination reveals a granular pigment similar to that in the kidneys. It is located chiefly in the endothelial and reticular cells of the medullary sinuses and occurs but sparsely in the cortical sinuses.

Collections of plasma cells and polymorphonuclear leukocytes, many of them eosinophils, may be seen in and around the medullary sinuses of the affected lymph nodes. Numerous mast cells may also be present.

Similar pigment deposits and cellular reactions may be seen in other lymph nodes as well but they are never as marked as in the renal nodes and never visible to the naked eye.

Changes in the spleen.

Sparse deposits of small yellowish granules may be seen in the reticular and endothelial cells of the red pulp. These granules give the same histochemical reactions as the renal pigment. Otherwise there are usually large deposits of blood pigment.

Changes in the liver.

The liver is never the site of macroscopic changes. Microscopically, however, a finely granular pigment may be seen in the Kupfer cells and in the liver cells. The deposits are very scanty and often seen in the Kupfer cells only. The pigment gives the same reactions as that in the kidneys.

\section{Bone marrow.}

Scattered, pin-point sized brownish dots may be seen in the fatty bone marrow, but characteristic pigment deposits were not demonstrable in sections of the marrow.

\section{SOLUBILITY OF PIGMENT}

Various concentrations of sulfuric acid, hydrochloric acid and acetic acid failed to remove the pigment from the tissue. Heating to $56^{\circ} \mathrm{C}$ did not increase the solubility of the pigment in the acids mentioned. Alcoholic acid solutions were also ineffective. Alkaline solutions, however, seemed effective. Exposure to a 1 per 
cent solution of sodium hydroxide or 1 per cent ammonia water caused partial removal of the pigment from the tissue.

The pigment was insoluble in alcohol, ether, chloroform, carbon tetrachloride and pyridine. Even boiling in alcohol, equal parts of alcohol and ether, and chloroform failed to remove the pigment.

\section{HISTOCHEMICAL EXAMINATIONS}

Examinations for hemosiderin, hematoidin, and bilirubin.

Properties concerning the solubility of the pigment seemed to be conclusive enough to exclude that it should belong to the haem group or to the early stages of the lipofuscins. In order to see, however, whether there could be an admixture of some of these pigments special reactions were performed. A positive Turnbull reaction for iron was given in 2 cases only. ${ }^{1}$ ) The 2 kidneys in which the pigment gave a positive reaction for iron were those of 2 heifers aged 6 and 8 months, respectively. As usual, the pigmentation was confined to the proximal convoluted tubules and their straight terminal portions. When stained with Nile blue sulfate, however, parts of the pigment did not take the stain but retained its original brownish or yellowish color. Treatment with 5 per cent oxalic acid for twenty hours removed the ironcontaining pigment, while that giving a positive Nile blue sulfate reaction remained. Thus two different pigments were present, viz., the iron-containing hemosiderin and an iron-free pigment. The latter gave the same reactions as the pigment in the remaining cases of black pigmented kidney.

A peculiar feature was demonstrated with regard to the two pigments present in the two kidneys. Even though both appeared in the same portions of the tubules, those containing much hemosiderin contained little of the iron-free pigment, and vice versa, although both types might be present in the same cell. In a single cross section of a tubule, a few cells chiefly containing iron-free pigment, and others chiefly containing hemosiderin were demonstrated. It appeared as if one pigment would debar the other.

Gmelin's test applied to black kidneys was negative. So was also the iodine test for bile pigment. This tests, however, seem

1) If no particulars are given, the histochemical reactions have been performed as devised by Pearse (1954). 
to fail in many instances even when they are applied to calves' kidneys discolored by bile pigment.

Fouchet's reagent, on the other hand, added dropwise to fresh frozen sections, will give a distinct bluish coloration of the bile pigment. This reaction was not observed in sections of black pigmented kidneys. The Fouchet test for bilirubin is far more sensitive than the Gmelin and iodine tests, and can obviously be used with advantage in histologic work.

Tests for lipofuscins.

Hueck (1912) has pointed out that Nile blue sulfate can be used to distinguish between lipofuscin and melanin. With the pigment studied it gave a blue to bluish green color which persisted also after treatment with 10 per cent hydrogen peroxide or 1 per cent acetic acid. This indicated a lipofuscin.

Application of the Schmorl test for lipofuscin resulted in a reduction of the ferricyanide to ferrocyanide giving the Prussian blue reaction in the presence of ferric salts, with the production of a blue coloration of all the pigment granules. Sections thus treated seemed to contain more pigment than the controls. This might be due to the presence in the renal epithelium of precursors of the pigment capable of converting ferricyanide into ferrocyanide.

Application of the long Ziehl-Neelsen method for acid fast lipofuscins showed most of the pigment granules to be acid fast. Only a few of the smaller granules did not take the stain. Mallory's method for hemofuscin (after Lillie) gave a positive reaction. This method, like that of Ziehl-Neelsen stains ceroid as well. Dam's method applied to fresh frozen sections prepared from formalin-fixed material failed to demonstrate peroxides in the pigmented cells.

The PAS reaction using Schiff's reagent prepared according to Barger and De Lamater was positive in some instances. In a few instances some of the pigment granules stained deep purplish red. Use was made of frozen sections prepared from formalinfixed material and material fixed in formalin and embedded in paraffin. In sections showing a positive reaction the large flakes or conglomerates of pigment granules attained a uniform deep red color or showed merely a red stippling on a yellowish brown ground. After acetylation the reaction failed to appear but a 
purplish red coloring of individual granules was observed following further treatment with $1 /{ }_{10} \mathrm{~N}$ potassium hydroxide.

This indicated a carbohydrate component but further analysis was nonconfirmative. This circumstance will be considered later in the text.

According to Pearse, the PAS reaction is positive only in certain intermediary stages of oxidation of lipides, while the PFAS reaction is positive over a wider range. The PFAS reaction was negative as performed according to Pearse as well as after Lillie. The chrome alum hematoxylin method for lipofuscins after Gomori was also negative. Fatsoluble colorant methods including Sudan III, oil red O, oil blue N, and Sudan black B gave a negative result.

The pigment was not double refractive to polarized light.

At high grades of oxidation, with formation of highly colored lipofuscins, the solubility of lipids in fat solvents as well as their ability to dissolve fat stains are said to diminish. Fluorescence and basopfilia, on the other hand, are said to be marked.

Primary fluorescence, however, could not be demonstrated in fresh or fixed material.

From the results of these tests it is evident that the pigment of black kidneys is not a member of the class of lipopigments. The fact that some of the granules stained purplish red by the PAS technique might be considered evidence of a polysaccharide structure.

Digestion with 0,1 per cent malt diastase in phosphate buffer at pH 6 after Lillie was therefore performed. The enzyme had no action upon the pigment, and the PAS reaction on sections exposed to the enzyme gave the same result as on the controls.

Estimation of dye-binding capacity for methylene blue (Dampsey and Singer) by direct histologic examination without the use

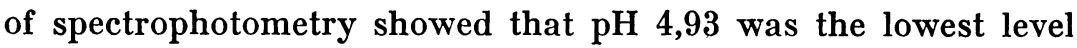
at which the pigment stained densely blue. At $\mathrm{pH} \mathrm{3,2}$ the blue color attained a shade of green. Even at $\mathrm{pH} \mathrm{2,62} \mathrm{there} \mathrm{was} \mathrm{not}$ complete extinction of binding capacity for methylene blue. At this level, however, the pigment granules showed so much of their own color that they appeared almost greenish with a shade of yellow.

Methods for mucopolysaccharides gave a negative result. There was no development of metachromasia with toluidine blue, and the pigment did not give the Preussian blue reaction by the 
dialyzed iron method of Hale. Nor did it give a blue stain with the combined dialyzed iron and PAS method (Ritter and Oleson). By the latter method a weak reddish stippling of some of the larger pigment flakes was observed.

The positive PAS reaction in parts of the pigment did scarcely indicate a mucoprotein or glycoprotein fraction as these substances are not considered to bind methylene blue at $\mathrm{pH}$ levels ranging as low as that in the case of this pigment (Pearse, 1949).

The gallocyanin-chromalun method for nucleic acids (Einar-

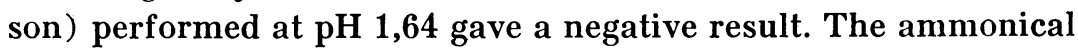
silver reaction for aldehydes using Gomoris hexamine silver solution gave no deposit of silver.

Tests for melanin and amino acids.

The Schmorl method and sometimes also long Ziehl-Neelsen method may be positive in the presence of melanin. Some decolorization of the renal pigment was observed following treatment with 10 per cent $\mathrm{H}_{2} \mathrm{O}_{2}$ for 24 hours, likewise with chlorate for 24 to 48 hours and by the use of chromic acid. A 5 per cent solution caused definite bleaching within one hour, while equal parts of 1 per cent chromic acid and 5 per cent $\mathrm{CaCl}_{2}$ had only slight effect.

Treatment with Fontana solution caused practically no alteration of the pigment, while hexamine silver (Gomori) caused a definite blackening.

The association of melanin with protein is emphesized by several authors. It is characterized as a chromoprotein. Some tests on amino acids were therefore performed.

It has been stated that melanin is a polymeribed derivative of indole. Ehrlich's p-dimethylaminobenzaldehyde reaction for indole, however, gave a negative result.

The Millon reaction (Bensley and Gersh modification) was negative. With the coupled tetrazonium reaction of Danielli the pigment stained strongly reddish brown. When the coupled tetrazonium reaction was preceded by mild heat $\left(60^{\circ} \mathrm{C}\right.$ for 10 minutes) and benzoylation for 16 hours, the pigment stained in a shade of deep reddish brown. The xantoproteic reaction (after Lillie) was difficult to judge because of a yellowish coloration of the surrounding tissue. After exposure to fumes of ammonia, however, the pigment stained in a definite shade of orange indicating a positive result. 
The Romieu reaction for tryptophan was negative, and so were also the Voisent-Fürth and ninhydrin reactions (all of them after Lillie). The ferricyanide method of Chevremont and Frederic for SH groups gave a positive result, while the performic acid-Schiff method for SS groups after Pearse gave a negative result.

In the ferricyanide method for $\mathrm{SH}$, which was performed on formalin-fixed sections, treatment with saturated aqueous $\mathrm{HgCl}_{2}$ was tried. After treatment for one hour the reaction still appeared, while sections treated for two hours reacted negatively. This seems to indicate SH groups as a cause of the reduction of ferricyanide.

Digestion of the pigment with pepsin and trypsin was tried with negative results. Use was made of tissue fixed in alcohol and embedded in paraffin, with and without removal of the paraffin from the sections before digestion. The technical arrangement was otherwise that described by Lillie.

The DOPA technique (Becker, Praver, Thatcher) failed to demonstrate DOPA-oxidase (tyrosinase) in the pigmented cells.

\section{Conclusions drawn from the histochemical examinations.}

Despite the fact that the pigment was found to share a number of reactions with the lipofuscins, it cannot be referred to as such. It was not soluble in fat-dissolving agents, and was not stainable with fat-soluble dyes; nor was it actively fluorescent or stainable with the chrome alum hematoxylin method.

It is not a member of the heam group, as it did not give a positive reaction for iron and did not react like hematodin or bilirubin. Properties with regard to solubility, absence of fluorescence and negative Gmelin's reaction exclude porphyrins.

The pigment is obviously of protein nature as evidenced by the positive coupled tetrazonium reaction and the demonstration of certain amino acids. Indole and tyrosin could not be demonstrated, nor tryptophan. The xantoproteic reaction, on the other hand, was possibly positive. As the reactions for tryptophan and tyrosin were negative, the positive xanthophoteic reaction might indicate phenylalanine, and the positive coupled tetrazonium reaction histidine. However, the failure to demonstrate tyrosin and tryptophan by histochemical methods does not exclude these substances, as they may be attached to the molecule in such a manner that the reactive groups are not liberated. 
The demonstration of SH groups may indicate the presence of cystein, while cystin is not demonstrated by the presence of SS groups. The fact that lipofuscins could be excluded and that the ferricyanide reaction for $\mathrm{SH}$ (Chevremont and Frederic) was negative after treatment of the sections with saturated aqueous $\mathrm{HgCl}_{2}$ for two hours must be considered definite evidence of the presence of $\mathrm{SH}$ groups.

The negative reactions for mucopolysaccharides and nucleic acid exclude these substances as a cause of the low methylen blue extinction values observed. Nor was there anything to indicate the presence of lipid complexes.

Properties with regard to solubility, the results of treatment with hexamin silver solution, and the effect of bleaching agents as compared with the results of other procedures indicate that the pigment is a melanin.

The fact that the indole reaction with p-dimethylaminobenzaldehyde was negative does not contradict a diagnosis of melanin as Lea (1949) has found the test negative with fully formed melanin.

Marked resistance to proteolytic enzymes is one of the characteristics of melanins.

The significance of the positive PAS reaction is not clear. A positive reaction with melanin has been observed by other authors as well. McManus (1949) considers it indicative of a carbohydrate component, but this is not likely here. Pearse in his Histochemistry suggests that melanin may be broken down in such a way that mild oxydation reveals aldehydes formed from the pigment itself, or that the pigment may be covered by a coating of oxidizable (unsaturated) lipids.

\section{ISOLATION OF THE PIGMENT}

Extraction of the pigment by means of alkaline solutions was found possible. In preliminary experiments, 1 per cent ammonia water seemed suitable for this purpose.

The highly pigmented cortical tissue of a kidney was cut in small pieces totalling $412 \mathrm{Gm}$. The tissue was extracted with ammonia water (1 per cent) at room temperature for three days. The dark brown, clear fluid was filtered off and the process repeated five to six times until most of the pigment had been removed from the tissue. The collected filtrate was then centri- 
fugated at 3,000 r.p.m. for 30 minutes. This gave a greyish white sediment which was discarded.

The clarified fluid was neutralized and mixed with an equal volume of a saturated solution of $\left(\mathrm{NH}_{4}\right)_{2} \mathrm{SO}_{4}$. A dark grey precipitate was formed. This was isolated by centrifugation for 30 minutes at 3,000 r.p.m., suspended in water, and dialized until $\mathrm{NH}_{4}-$ and $\mathrm{SO}_{4}$-free. This gave a bluish black, almost clear fluid, which in thin layers appeared dark brown. A minute amount of insoluble matter, greyish white in color, was removed by centrifugation.

After neutralization, $\mathrm{KCl}$ to $0.5 \mathrm{M}, \mathrm{NaHCO}_{3}$ to $0,03 \mathrm{~N}$, and pancreatin were added to the clear supernatant. The $\mathrm{pH}$ of the mixture was 7.8. A little toluol ( 0.5 per cent) was also added in order to prevent bacterial growth. The mixture was then incubated at $37^{\circ} \mathrm{C}$ for five days and was shaken at frequent intervals during the initial period of incubation. Prior to digestion with pancreatin the biuret test gave a light pinkish to violet color. The ninhydrin and xantoproteic reactions were also positive. The color of the pigment, however, made evaluation of the latter reaction difficult. Millon's reaction was negative.

After pancreatin digestion the biuret test was negative but the ninhydrin reaction strongly positive. The xantoproteic reaction was also still positive and the Millon reaction negative.

The mixture was then dialyzed against tap water for three days and centrifugated for one hour at 2,000 r.p.m. The supernatant was clear and dark brown and gave a negative reaction with the ninhydrin test. The xantoproteic reaction, however, was still positive.

By addition of an equal volume of absolute alcohol to the clear supernatant a dark brown flocculent precipitate was formed. The mixture was centrifuged (2,000 r.p.m. for 20 minutes) and the precipitate was washed and dried with alcohol and ether. The dried residue formed a black, light powder. The amount thus extracted from a single kidney totalled $1.68 \mathrm{Gm}$. However, the pigment was not entirely removed from the tissue and some of it was lost by breakage of a couple of centrifuge tubes in the processing. The total content of pigment surely must have amounted to at least $2 \mathrm{Gm}$. 
Examination of the isolated pigment.

The blackish brown powder was "soluble" in water at neutral and alkaline reactions. Precipitation occurred following addition of dilute hydrochloric acid or acetic acid. The iso-electric point was at $\mathrm{pH} 4.7$ to 4.9 . Boiling with concentrated nitric acid gave a light yellow solution which upon addition of $\left(\mathrm{NH}_{4}\right) \mathrm{OH}$ or $\mathrm{NaOH}$ in excess attained an orange color. The biuret, ninhydrin and Millon reactions were negative. Addition of $\mathrm{H}_{2} \mathrm{O}_{2}$ to an aquous "solution" of the pigment caused a definite bleaching.

Attempts at spectrophotometric analysis of an aquous "solution" of the substances were unsuccessful as no specific extinctions were obtained. Filtration of the "solution" through different grades of filters was carried out. The coloring matter was retained by a Seitz Germicide EK filter but passed easily through different grades of gradocol membranes including the lowest grade with an APD of $0.22 \mu$.

Examination under the electron microscope showed that the aqueous "solution" formed a thin film composed of very small particles. This might indicate that the pigment with water forms not a true solution but a kind of sol or gel.

The content of nitrogen as determined by Kjeldahl's micromethod was 9.5 per cent. The contents of $\mathrm{C}, \mathrm{H}$, and $\mathrm{ash}^{\mathbf{1}}$ ) were 44.9 per cent, 6.4 per cent and 4.2 per cent, respectively. The ash contained approximately 21 per cent of iron, comparatively large amounts of $\mathrm{Mg}$ and $\mathrm{Ca}$, small amounts of $\mathrm{Zn}, \mathrm{Al}, \mathrm{Si}$, and $\mathrm{Cu}$, and traces of other substances. ${ }^{2}$ )

Analysis of the isolated pigment by means of paper chromatography was also attempted. Hydrolysis was performed under pressure at $110^{\circ} \mathrm{C}$ with concentrated hydrochloric acid, and with saturated barium hydroxide using sealed glass ampoules.

Chromatography revealed a number of different amino acids. Lysine, asparaginic acid, glutamic acid, glysine, alanine, valine, isoleucine, and phenylalanine were present in comparatively large and easily demonstrable amounts. A point meriting special attention is that tyrosine was very sparsely represented. Further, the analysis disclosed the presence of cystin-cystein, "fast arginine",

1) Carried out at Universitetets Kjemiske Institutt, Oslo, by Cand. Real. Y. I. Solberg.

2) Spectrographic analysis carried out at Biokjemisk Institutt, Norges Veterinærhфgskole, Oslo, by Cand. Real. G. N. Havre. 
proline, methionine sulfone, treonine, serine, arginine, and possibly also histidine. Corcerning "fast arginine" it has been demonstrated by Dent (1948) in blood and tissue extracts. He considers it "a guanidin compound derived from lysine”.

A hydrolysate obtained by the use of 25 per cent sulfuric acid was also studied. The chromatographic pattern of this hydrolysate accorded closely with those of the hydrochloric acid hydrolysates. Serine and treonine, however, were clearly distinguishable. ${ }^{1}$ )

Both acid and alkaline hydrolysis left a small amount of a black insoluble residue, the rest pigment.

\section{Comments to the chemical analysis.}

The pigment was extractable with weak solutions of strong alkali and weak solutions of ammonia. From the extracts it could be isolated in pure form, as it was found to follow the pseudoglobulin fraction. The pigment resisted digestion with pancreatin and pepsin and could thus be separated by enzymic digestion from other proteins with similar physical properties.

The molecular ratio of carbon and nitrogen in the pigment was 5.5 to 1 , and its content of iron was estimated to approximately 0.9 per cent.

The pigment was found to give some of the color reactions of proteins. This, colated with its physical properties and its content of amino acids, indicate a substance of protein nature.

\section{EXAMINATION OF URINE}

Urine from cattle with black kidneys had a normal color. It did not darken more than urine from normal animals on standing.

Addition of a few drops of ferrichloride solution to urine acidified with sulfuric acid (after Jaksch-Pollak) in most instances produced a slight brownish clouding with subsequent formation of a greyish brown or brownish black sediment. Similar changes were observed by the use of a solution of potassium bicromate instead of ferrichloride. Urine from normal animals reacted in a similar manner.

With Thormählen's nitroprusside test, urine from cattle with

1) The chromatography was carried out by Magister Vibeke Køpke, Universitetets Kjemiske Institutt, Oslo. 
black kidneys like urine from normal animals in most instances gave a faint green to greenish blue color. Ammoniacal silver nitrate solutions were reduced by urine from normal cattle as well as urine from cows with black kidneys.

The reactions mentioned thus provided no evidence of the presence of melanin or melanogens in the urine. Negative reactions were also given by urine to which a small amount of the isolated pigment had been added.

A quantity of $750 \mathrm{ml}$ of urine pooled from 3 different cows with pigmented kidneys was evaporated in vacuo to $175 \mathrm{ml}$ which was mixed with an equal volume of saturated $\left(\mathrm{NH}_{4}\right)_{2} \mathrm{SO}_{4}$ solution. A slight, yellowish brown precipitate was formed. This was dialyzed against running water for three days. The contents of the dialysis bag were centrifuged and a clear yellowish fluid was obtained. To this, alcohol was added until formation of a yellowish brown precipitate, which was recovered by centrifugation. The dried residue formed a brownish dust-like powder.

With 1 percent of ammonia water the powder gave a clear, yellowish brown fluid. Boiling with concentrated $\mathrm{HNO}_{3}$ gave a clear, light yellow fluid which upon addition of strong alkali attained an orange color. Addition of $\mathrm{H}_{2} \mathrm{O}_{2}$ to an ammoniacal "solution" of the powder caused a definite bleaching of the color.

Some of the powder was hydrolyzed with concentrated $\mathrm{HCl}$ at $110^{\circ} \mathrm{C}$ for 24 hours and prepared for chromatography. The amino acid pattern was the same as that of the hydrolyzed pigment isolated from kidney tissue except for proline which did not appear in the chromatograms. This might have been due to the small amount of substance used for the hydrolysis as the proline spot was very faint also in chromatograms of the isolated renal pigment. A small content of monoiodetyrosine or diiodotyrosine was also demonstrated in the substance isolated from the urine.

Conclusion drawn from the urin analysis.

Examination of sections and the urin analysis indicate that the pigment is excreted in the urine but in very small amounts. Urine from animals with black kidneys differ with regard to color reactions and the effect of oxidizing agents from urine from individuals with alkaptonuria, Addison's disease, ochronosis or melanin-containing tumors. Even the addition to the urine of 
pigment isolated from black pigmented kidneys fails to produce the reactions given by human urine containing melanin or/and melanogens.

\section{OCCURRENCE OF BLACK KIDNEYS}

During a visit to a slaughter yard in Copenhagen I counted 43 cases of black pigmented kidneys among 763 slaughter beasts. This corresponds to an incidence of 5.6 per cent. The age of the animals in 2 instances was $1 / 2-1$ year, in 4 instances $1-2$ years, in 11 instances $2-3$ years, and 26 instances more than 3 years.

The degree of pigmentation showed no relation to age or sex. A definite relation to other diseases or pathologic changes apart from those in the kidneys as described in this paper has never been demonstrated. The animals with black kidneys were all of the "Rødt Dansk Malkekvæg" breed. A certain number of cattle of the Jersey and "Sortbroget Dansk Malkekvæg" breeds were also slaughtered in the same yard, but I never saw any case of black kidneys among them. Mr. N. B. Larsen, inspector veterinarian, Randers, who upon my request kindly has made inquiries into these matters at the slaughterhouse of Randers, stated that the anomaly seemed to occur in members of the Danish red cattle breed only.

In Norway the occurrence of black pigmented kidney is extremely rare. Many of the meat inspectors whom I have contacted, have never observed the disease. During the past two years I have also contacted several slaughter houses in order to obtain kidneys of cattle with this anomaly, but so far I have only obtained 3 specimens, all of them from animals slaughtered in Oslo. The breed of these animals could not be ascertained. A possible relationship to the "Rødt Dansk Malkekvæg" breed cannot be excluded, as breeders have occasionally been imported from Denmark to this country.

In Sweden a few cases have been observed by professor $S$. Rubarth (personal communication). In Germany the anomaly is obviously extremely rare as indicated by the publication of Roth, who was able to collect only 2 cases in addition to 3 museum specimens received by Th. Kitt. Dr. H. Köhler of the Veterinary College of Hannover in a personal communication stated that the anomaly is exceedingly rare in Germany.

The anomaly is also a rarity in Holland as indicated by a publication of Bos who described a single case. Professor E. $L$. 
Stubbs at the University of Pennsylvania in a personal communication stated that he had never observed this particular type of pigmentation of the kidneys among cattle in U.S.A.

\section{DISCUSSION}

According to data revealed in this study, the pigment found in black kidneys must be characterized as a melanin. The term melanosis renum bovis is therefore suggested for the anomaly.

Greenstein, Turner and Jenrette (1940-41) isolated a watersoluble melanin-containing pseudoglobulin from malignant melanoma of mice (melanoma $\mathrm{S}-91$ ). This pigment seems to have many characteristics common with the pigment isolated from black kidneys of cattle. The pigment studied by Greenstein et al. was found to contain 11 per cent of nitrogen. Direct chemical analysis revealed the presence of cystine-cysteine, methionine, tyrosine and tryptophane. The recovered renal pigment contained 9.5 per cent nitrogen and a large number of amino acids including those found by Greenstein et al. in melanoma-melanin with the exception of tryptophane.

Serra (1946) isolated a melanoprotein from hair. In the case of this pigment there was demonstrated very strong linkage between what he calls melanoid and protein. To break this linkage, treatment with $\mathrm{HCl}$ was required. The melanoproteins investigated by Serra showed great resemblance to pseudoglobulin with regard to solubility and composition.

As pointed out by Mason (1948) the drastic methods required to isolate the melanin make it difficult to determine its mode of combination with other components within the pigment granules. The technique used for isolation may thus influence the analytic result. However, the color-bearing component of melanins is often very stable as in the case of the pigment studied. This chromoprotein resisted boiling with $6 \mathrm{~N} \mathrm{HCl}$. Boiling with concentrated $\mathrm{HCl}$ under pressure $\left(110^{\circ} \mathrm{C}\right)$ was necessary to achieve hydrolysis. Consequently it seems justified to conclude that the color-bearing component must be firmly attached to the substances demonstrated by chromatography of the hydrolysates.

Histochemical methods failed to demonstrate iron in the pigment despite an iron content of approximately 0.9 per cent. This accords with the properties of other melanins which do not give positive iron reactions despite an iron content of up to 2.7 per cent (Neuberg, 1911). 
Fürth, Friedrich and Kaunitz (1935) investigated melanin isolated from urine in melanosarcomatosis and reported the molar ratio of $\mathrm{C}$ to $\mathrm{N}$ in their own material and ratios collected from other studies of sarcoma-melanin. The values ranged from 4.2 to 6.7 in the various instances, averaging 5.6. In the pigment isolated from black kidneys the $\mathrm{C} / \mathrm{N}$ ratio was 5.5

The problem concerning the site and mode of formation of the melanin in melanosis renum bovis is rater obscure. The pigment granules are almost exclusively found in the proximal convoluted tubules and their straight terminal portions. Careful examination may reveal sparse deposits in macrophages in the interstities and in endothelial cells of the lymphatic vessels. Deposits are also found in the lymph nodes but always in larger amounts in the renal lymph nodes than in others. Sparse deposits may also be found in the liver and to a minor degree in the spleen. These circumstances seem to indicate that the pigment is formed in the kidneys. Some of it is carried via the lymphatics to the regional lymph nodes which apart from the kidneys are the structures containing the largest amounts. A small proportion of pigment not being retained in the renal lymph nodes will enter the general circulation from which it is taken up by cells belonging to the reticuloendothelial system in various parts of the body, e.g., lymph nodes, liver and spleen. The conversion of melanin into colorless derivatives is believed to take place in the liver. The pigment is therefore likely to be found in the liver and was actually demonstrated within the liver cells as well as in the Kupffer cells.

When melanin escaping into the blood is excreted by the kidneys, there is always a deposition of small uniform melanin granules in the tubular epithelium. Personally I have observed this feature in melanosarcomatosis in horses and following intravenous injection of melanin (isolated from bovine kidneys) in rabbits. However, renal pigmentation is never as marked as in cases of black kidneys.

The fact that the pigment in some instances is found chiefly in the proximal convoluted tubules and in others chiefly in the straight terminal portions of the convoluted tubules or in definite parts of the structures mentioned, but always highly systematized in the individual case, seems to indicate that conditions within the cells are responsible for the pigmentation. In the event of a sheer excretion of preformed pigment, a more even distribution 
of the pigment in the entire secretory portion of the nephron would be likely. The pigment is obviously strongly anchored to the tubular cells and not easily excreted, as merely sparse amounts are found in the urine even in the presence of severe pigmentation of the kidneys.

The failure to demonstrate DOPA-oxidase in the renal epithelium by the method of Becker et al. does not exclude the kidneys as the site of formation of the pigment. Blaschko and Jacobsen (according to Kopac) found that cytochrome oxidase + cytochrome c were able to oxidize DOPA. This system is widely distributed in animal tissue. Large amounts have been demonstrated in kidney tissue of rats.

There is reason to believe that some kind of allergic reaction may give rise to the development of certain types of pigmentation such as, for instance, that observed during pregnancy in women (Robert and Zeller). In this connection, attention is drawn to the fact that numerous mast cells were seen in the tissue of practically all the "black kidneys" examined in this study even in the absence of demonstrable fibrous tissue proliferation. On the other hand, numerous mast cells may be seen in the absence of melanin deposits in the renal parenchyma. This type of renal pigmentation can therefore hardly be ascribed to an allergic reaction alone, although such a mechanism may possibly be involved as a precipitating factor. Thus the question of a hereditary predisposition naturally arises.

Otherwise it may be worth mention that Kimelstiel (1938) and others have emphasized that hematogenous, interstitial nephritis often reflects an allergic, hyperergic reaction to foreign protein or protein disintegration products rather than a bacterial infection. In the present study chronic inflammatory changes were found by statistical analysis to occur with greater frequency in black kidneys than in the controls. This does not necessarily indicate an inflammatory response to the pigmentation, but perhaps rather the chronic inflammatory changes as a predisposing factor for the pigment formation.

A factor of possible importance is the circumstance pointed out by Figge (1948), namely, that a shift in the redox potential of the cells may influence the formation of melanin. He found that phenol indophenol stimulated the melanogenesis in connective tissue cells. He explains the feature thus: "It does this by virtue of its capacity to shift the redox potential of these cells 
toward a higher positive level." Robert and Zeller (1941) have also maintained the idea of the redox potential. Robert (cit. Robert and Zeller) found that certain substances (thyroxin and adrenalin) as injected intradermally in rabbits, by virtue of a stimulating effect on the local metabolism were able to increase local pigment formation, without inflammatory changes being involved.

The frequent occurrence of melanosis renum bovis in a certain breed ("Rødt Dansk Malkekvæg”) may suggest that hereditary factors are involved. In view of the absence of the anomaly in other breeds in the same areas, conditions concerning the local soil and vegetation can hardly be considered a causative factor.

\section{ACKNOWLEDGEMENTS}

My thanks are due to professor J. P. Sjolte and dr. O. Grini for their help and interest in this work; also to Mr. E. Waasjø for his assistance and to Mrs. Vibeke Køpke, Mr. Y. I. Solberg and Mr. N. Havre for having performed the special chemical analysis mentioned in the text.

\section{SUMMARY}

The peculiar type of pigmentation of the kidneys in cattle commonly known as "black kidneys" has been studied.

1) The pigmentation is localized to the neck, the proximal convoluted tubule and its straight terminal portion. Deposits may occasionally be observed in the parietal layer of the capsule of Bowman. Outside the kidneys very small amounts of pigment may be found in the lymph nodes, particularly those of the kidneys, in the liver, and in the spleen. 2) Focal, productive inflammatory changes in the renal interstitial tissue were found by statistical analysis to occur with greater frequency in black pigmented kidneys than in the controls.

3) Histochemical study and analysis of the isolated pigment suggest that the pigment is a true melanin. The term melanosis renum bovis is therefore suggested for the condition.

4) Chromatoraphy of acid and alkali hydrolysates prepared under pressure $\left(110^{\circ} \mathrm{C}\right)$ demonstrated the following amino acids in the purified product: Lysine, asparaginic acid, glutamic acid, glysine, alanine, valine, isoleucine, phenylalanine, cystine-cysteine, "fast arginine", proline, methionine sulfone, treonine, serine and possibly histidine and tyrosine.

The pigment contained 9,5 per cent nitrogen, 44,9 per cent carbon and 6,4 per cent hydrogen. The ash content was 4,2 per cent, and the content of iron 0,9 per cent. 
5) The pigment is excreted in the urine but in very small amounts. Urine containing the pigment does not give the same reactions as urine from individuals suffering from melanin-containing tumors, Addison's disease, ochronosis or alkaptonuria.

6) Certain circumstances indicating the renal parenchyma as the site of formation of the pigment are discussed.

7) The far more frequent occurrence of the anomaly in a certain breed (Rødt Dansk Malkekvæg) than in others suggests a hereditary factor. Some kind of local allergic reaction may possibly also be involved.

\section{REFERENGES}

Bos, A. W. A.: T. Diergenesk. 1936, 63, 707.

Dent, C. E.: Biochem. J. 1948, 43, 169.

Figge, F. H. J.: The Biology of Melanomas. Spec. Publ. New York Acad. Sci., 1948, 4, 405.

Fürth, O., Friedrich, A. \& Kaunitz, H.: Wien klin. Wschr. 1935, 48, 655. Glich, D.: Techniques of Histo- and Cytochemistry, New York 1949.

Greenstein, J. P., Turner, F. C. and Jenrette, W. V.: J. nat. Cancer Inst. $1940-41,1,377$.

Hemmert-Halswick, A.: Arch. Tierheilk. 1929, 60, 553.

Hueck, W.: Pigmentstudien, Diss., München 1912.

Joest, E.: Spez. Path. Anat. d. Haust., Berlin 1924.

Kimmelstiel, P.: Amer. J. Path. 1938, 14, 737.

Kitt, Th.: Lehrbuch d. Path. Anat. d. Haust., Stuttgart 1927.

Kopac, M. J.: The Biology of Melanomas, Spec. publ. New York Acad. Sci. 1948, 4, 423.

Lea, A. J.: Arch. Path. 1949, 47, 211.

Lillie, R. D.: Histopathologic Technic and Practical Histochemistry, New York 1954.

Mason, H. S.: The Biology of Melanomas. Spec. publ. New York Acad. Sci. 1948, 4, 399.

McManus, J. F. A.: Amer. J. Path. 1949, 25, 800.

Neuberg, C.: Der Harn, Berlin 1911.

Nieberle \& Cohrs: Lehrbuch d. Spex. Path. Anat. d. Haust., Jena 1954.

Pearse, A. G. A.: J. clin. Path. 1949, 11, 81.

Pearse, A. G. E.: Histochemistry, London 1954.

Robert, P. \& Zeller, E. A.: Schweiz. med Wschr. 1941, 22, 1605.

Roth, L.: Mh. prakt. Thierheilk. 1903, 14, 367.

Serra, J. A.: Nature 1946, 157, 771.

\section{ZUSAMMENFASSUNG \\ Melanosis renum bovis.}

Die mit „schwarzer Pigmentniere“ bezeichnete eigentümliche Nierenpigmentierung beim Rind wurde untersucht.

1) Der Sitz des Pigmentes ist der gekrümmte und gerade Abschnitt des Hauptstücks, das Halsstück und in seltenen Fällen das parietale 
Blatt der Bowmanschen Kapsel. Ausser den Nieren kann das Pigment in geringeren Mengen in den Lymphknoten - und dann besonders in den Lymphknoten der Nieren - , in der Leber und in der Milz wahrgenommen werden.

2) Im vorliegenden Material wurde ein häufigeres Vorkommen fokaler, produktiver Entzündungsprozesse in den Interstitien bei schwarzen Pigmentnieren nachgewiesen als in den Kontrollen.

3) Auf Grund histochemischer Untersuchungen und von Analysen des extrahierten, gereinigten Pigments müsse dasselbe als ein Melanin bezeichnet werden. Wegen der Art der Pigmentierung wird für den Zustand folgender Name vorgeschlagen: Melanosis renum bovis.

4) Bei der Chromatographie von unter Druck $\left(110^{\circ} \mathrm{C}\right)$ hergestellten Säure- und Alkalihydrolysaten wurde eine Reihe von Aminosäuren in dem extrahierten Pigment nachgewiesen: Lysin, Asparaginsäure, Glutaminsäure, Glycin, Alanin, Valin, Isoleucin, Phenylalanin, CystinCystein, „Fast-Arginin“, Prolin, Methioninsulfon, Theonin, Serin und möglicherweise Histidin und Tyrosin. Im übrigen wurde festgestellt: $\mathrm{N}-9,5 \%, \mathrm{C}-44,9 \%, \mathrm{H}_{2}-6,4 \%$ und Asche 4,2\%. Der Eisengehalt belief sich auf $0.9 \%$.

5) Das Pigment wird mit dem Harn in sehr kleinen Mengen ausgeschieden. Der Harn gibt jedoch nicht dieselben Reaktionen wie der Urin von Individuen mit melaninhaltigen Geschwülsten, Addisons Krankheit, Ochronose oder Alkaptonurie.

6) Es werden einzelne Umstände besprochen, die darauf hindeuten können, dass das Pigment im Nierenepithel gebildet wird.

7) Das weit häufigere Vorkommen der Anomalie bei einer bestimmten Rasse (dem Roten Dänischen Milchvieh) als bei anderen Rassen kann dafür sprechen, dass erbliche Verhältnisse für die Entstehung der Anomalie eine Rolle spielen. Möglicherweise kann auch ein gewisser lokaler, allergischer Reaktionszustand mitwirken.

\section{SAMMENDRAG}

\section{Melanosis Renum Bovis.}

Det er foretatt en unders $\varnothing$ kelse av den særegne og eiendommelige nyrepigmenteringen hos storfe som går under betegnelsen „sort pigmentnyre".

1) Pigmentets sete er hovedstykkets buktete og rette avsnitt, halsstykket og i sjeldne tilfelle det parietale blad av den Bowmanske kapsel. Utenom nyrene kan pigment finnes i mindre mengder i lymfekjertlene - da især i nyrenes lymfekjertler —, i leveren og i milten.

2) Det er i det foreliggende materiale påvist en hyppigere forekomst av fokale, produktive betennelsesprosesser $i$ interstitiene ved sorte pigmentnyrer enn $i$ kontrollene.

3) Ved histokjemiske unders $\emptyset$ kelser og ved analyser av det ekstraherte, rensete pigment, er det funnet å burde betegnes som et melanin. På 
grunn av pigmenteringens art foreslås følgende navn for tilstanden: Melanosis renum bovis.

4) Ved kromatografering av syre- og alkalihydrolysater fremstillet under trykk $\left(110^{\circ} \mathrm{C}\right)$ er det påvist en rekke aminosyrer $\mathrm{i}$ det rensete produkt: Lysin, asparaginsyre, glutaminsyre, glysin, alanin, valin, isoleucin, fenylalanin, cystin-cystein, „, fast-arginin “, prolin, methioninsulfon, treonin, serin og muligens histidin og tyrosin.

Ellers er det funnet: $\mathrm{N}-9,5 \%, \mathrm{C}-44,9 \%, \mathrm{H}_{2}-6,4 \%$ og aske $4,2 \%$. Jerninnholdet er bestemt til $0,9 \%$.

5) Pigmentet utskilles i urinen i meget små mengder. Urinen gir dog ikke de samme reaksjonene som urin fra individer med melaninholdige svulster, Addison's syke, ochronose eller alkaptonuri.

6) Det er omtalt enkelte forhold som kan tyde på at pigmentet dannes i nyreepitelet.

7) Anomaliens langt hyppigere forekomst hos en bestemt rase (Rødt Dansk Malkekvæg) enn hos andre raser, kan tyde på at arvelige forhold spiller en rolle for dens opståen. Muligens kan også en viss lokal, allergisk reaksjonstilstand virke med.

(Received December 12. 1958). 